\title{
Migrant Smuggling: Novel Insights and Implications for Migration Control Policies
}

\author{
Anna Triandafyllidou \\ anna.triandafyllidou@eui.eu
}

Published in The ANNALS of the American academy of political and social science, 2018, Vol. 676, No. 1, pp. 212-221

DOI: $10.1177 / 0002716217752330$

Anna Triandafyllidou is a professor in the Global Governance Programme (GGP) at the Robert Schuman Centre for Advanced Studies (RSCAS), European University Institute. Within the GGP she coordinates the research area on cultural pluralism. She is the editor-in-chief of the Journal of Immigrant and Refugee Studies.

\begin{abstract}
This article offers a critical review of how migrant smuggling arises out of restrictive migration policies and how it has become increasingly sophisticated and professionalized. Reflecting on the innovative empirical findings presented in the contributions to this volume of The ANNALS, I highlight how migration control has hardened borders, disrupted cross-border flows of goods and people, and transformed local economies. Understanding better the relationship between migration control policies and migrant smuggling and the social and moral nature of the agentcustomer transactions has important implications for the policies adopted to address irregular migration and migrant smuggling on both sides of the Atlantic.
\end{abstract}

Keywords: migrant smuggling; passeurs; migration control; enforcement; moral economy;

Migrant smuggling is commonly represented through images of desperate people crossing inhospitable territories, notably the Arizona Desert from Mexico to the United States, and the Sahara Desert from Niger to Libya or Algeria, and of course the Mediterranean Sea to the Italian or Greek shores. Migrant smugglers are often portrayed in the media as callous criminals who send derelict and overcrowded dinghies across the Mediterranean. Or as unscrupulous coyotes who do not hesitate to abandon their customers-victims in the desert. The common element in these representations is death, abuse, severe deceit, and exploitation. Smugglers are portrayed as the perpetrators of criminal acts for profit. They benefit from the poor and vulnerable of the world who seek a better life and work opportunities in foreign countries. Their customers, the migrants, are seen as victims of ruthless criminal networks (Kyle and Koslowski 2001; European Commission 2015). This volume of The ANNALS goes against this conventional wisdom and dominant media discourse to argue that migrant smuggling is a complex phenomenon, that portraying smugglers as criminals and migrants as their victims oversimplifies a nuanced relationship, and that we need to think harder and dig deeper into realities on the ground, not least through qualitative empirical research and through comparative analysis, to understand the relationship between migrant smuggling and migration control policies.

The aim of this policy article is to review how migrant smuggling arises out of restrictive migration policies and how it has become increasingly sophisticated and professionalized. 
Reflecting on the innovative empirical findings presented in the contributions to this volume of The ANNALS, I highlight how migration control has hardened borders, disrupted cross border flows of goods and people, and transformed local economies. While the "smuggling business" turnover has dramatically increased, previously custom passeurs have turned to professionalized and well-equipped networks. In addition, I seek to illustrate how monetary transactions are embedded in wider systems of social relationships and what several of the authors contributing to this volume (e.g. Achilli, Maher, Majidi, Brachet, Ayalew) conceptualize as moral economies and wider systems of social relationships. While these relationships by no means justify the work of migrant smugglers they point to the relevance of historical patterns (see for instance StoneCadena and Velasco, this volume) and to the wider economic and political factors that play a part in migrations (see for instance Majidi, but also Ayalew and Gonzalez). Understanding better the relationship between migration control policies and migrant smuggling and the social and moral nature of the agent-customer transactions has important implications for the policies adopted to address irregular migration and migrant smuggling on both sides of the Atlantic.

\section{Irregular Migration and Migrant Smuggling}

The causes of irregular migration broadly lie in the intersection among people's search for life prospects, labor market demand, and restrictive immigration controls. This is of course no news in the study of international migration and yet there is something qualitatively different about migration today by comparison to the early twentieth century and even to the 1970s or 1980s. While globalization has intensified, integrating all countries into a global economy, expanding trade, intensifying communication, and making distant production systems interdependent, one of its naturally ensuing phenomena, notably the movement of people, is increasingly stiffened and restricted. In this sense, we may argue that irregular migration and migrant smuggling are phenomena of the late twentieth and early twenty-first centuries. This does not imply that there were no cross-border flows prior to this time or that all such flows were documented. It signals that hard territorial and digital ${ }^{1}$ borders have started solidifying mostly since the 1970 s and particularly in the last 20 years. This has codified flows as irregular/illegal (see also Düvell 2006) and led to the emergence of social and criminal networks aimed at facilitating cross border movement where movement is not legally authorized (Massey et al 2017; Salt and Stein 1997; Triandafyllidou and Maroukis 2012). In other words, we need to reconceptualize irregular migration as a structural feature of late-modern society rather than as an exception or social pathology.

Migrant smuggling emerges when and where borders are fixed, relatively impermeable, and protected by a border bureaucracy, which includes border crossing points, border guards, passport controls, entry visas, and stamps on one's passport when entering or leaving a country (Mountz 2010). This bureaucracy involves a range of border actors including not only state authorities and border guards but also nongovernmental organizations, international organizations, and of course migrant smuggling and human trafficking networks. Thus, people who wish to move to a new country without appropriate authorization may organize their trip on their own or with the help of family and friends based at the country of transit or destination but also increasingly rely on specialized networks of facilitators, passeurs, coyotes, handlers, or also scaffisti. This happens as a direct consequence of the very mechanisms and instruments mobilized to control borders. The higher the hurdles the more professionalized the assistance unauthorized migrants (and asylum seekers) will need. 
As Kyle and Koslowski (2001, 5) argued more than a decade ago, the smuggling of migrants into countries where they are not allowed to enter is not new, what is new is the global spread and development of the phenomenon. Sixteen years later, in 2017, there has been a development of the human smuggling and trafficking networks in the breadth and size of their criminal activities and business turnover - notably the amount of money involved in these two sectors as fees paid or profit made from these two activities - and a growth in the concern of governments and international organizations in combating these two related phenomena. Indeed the smuggling of migrants in general, as well as into Europe in particular, has been a priority for the United Nations Office on Drugs and Crime (UNODC) and its special antismuggling and antitrafficking training programs. Trafficking in human beings, an issue closely related to human smuggling, has also become a priority ${ }^{2}$ for international organizations such as the International Organisation for Migration (IOM). Most recently, the EU created a special office within EUROPOL called the European Migrant Smuggling Centre. ${ }^{3}$

\section{The Challenge for Policy}

Increasing restrictions on migration or asylum seeking risks perpetuating a vicious circle: the restrictions generate irregular migration, increasing the risks and costs to migrants and their dependence on smuggling networks, the latter of which turn to more sophisticated methods to avoid controls, and hence of course provide reasons for even more restrictions and heightened controls. In addition, irregular migration routes and smuggling activities further blur the distinction between different categories of migrants, as asylum seekers and economically motivated migrants share the same routes, services, and networks (Van Liempt 2007, 14; Koser 2010; Van Hear, Brubaker, and Besa 2009).

There are four distinct issues that cast light on the dynamics of this vicious circle. First, borders that used to be formal but very permeable are being hardened, disrupting and transforming cross border exchanges and movements. Second, migrant facilitation activities should be understood as embedded in local economies, often through the involvement of local "travel” agents of various sorts. Third, these loose networks operate through a combination of economic motivation and profit, as well as social meanings of trust and community in a highly insecure environment that needs to be appraised in all its complexity to effectively understand the roots of migrant smuggling. Fourth, the increased restrictions and police violence at the border and in transit leads to the transformation of such loose networks to more professionalized, organized and, indeed, criminal networks. While open borders may not be viable, the current emphasis on border securitization and externalization of controls to transit countries (neighboring and more distant to the United States and the EU) contributes to the professionalization and criminalization of smuggling networks while it does not stop irregular migration flows because the motivations to migrate, both economic and political, are too strong. There is an urgent need for a more comprehensive approach that mainstreams local economic and community factors in the effort to manage unauthorized migration. I outline some of these aspects next.

\section{Hardening borders}

First, borders that used to be formal but permeable are being hardened, disrupting and transforming cross border exchanges and movements. Brachet (this volume) highlights the dynamics of the cross Saharan flows of goods, which also includes transporting people across Niger to Libya. The city of Agadez was a main transit point, a traditional stop for old caravan 
routes, that was buzzing as a stopover for trucks that would transport goods back and forth. Prospective irregular migrants would speak directly to these lorry drivers and arrange prices for their transportation. Both the lorry drivers and the migrants would see this as an informal transportation service rather than as an unauthorized border crossing. West Africans seeking employment in Algeria and Libya usually took this migratory route; only a few among them would end up farther north to attempt a crossing into Europe (Pliez 2003). The truck drivers who would today qualify as migrant smugglers were understood, according to Brachet, as traders.

However, the breakdown of the Khaddafi regime in Libya has created lawlessness and chaos, and disrupted the national economy that was the source of employment for West African migrants. Thus, migration has moved farther north through the Mediterranean, to Europe. European countries have responded by improving their sea border controls and by externalizing migration controls to transit countries. Thus, as Brachet so aptly explains, the border between Niger and Libya and Algeria has been hardened and the governments of those countries pressured to tighten border controls. International organizations opened local offices to manage cross border movement. Police and border forces were pressured to change tactics, stopping and controlling lorries. Passing became more risky, bribes increased, and the means of transport changed. Cross-border movement shifted from informal to clandestine. Drivers of commercial lorries were no longer willing to run the risk of carrying irregular migrant workers. However, security guards from the gold mines near Agadez were ready to step in to transport migrants. Informal travel agencies closed and migration facilitation became more organized; more expensive; riskier, as it had to cross through desert points rather than formal border crossings; and more violent, as local police and military forces in Niger sought to stop the flows. New laws criminalized facilitation and transportation of migrants.

A similar process has been taking place in Mexico, as Guevara Gonzalez illustrates in this volume. Pressures on Mexico to control Central American migration through the country toward the United States has led to the tightening of Mexican borders and the criminalization of informal movements. In this case, the border has become an internal boundary. Migration controls take place rat public places such as through random controls at highways and in public squares, or bus and train stations or even on board in the trains. The journey has become particularly risky and unsafe (see also Sanchez 2015), which has increased the need for migrants to hire professional smugglers. This need has contributed to the professionalization of smuggler services. Guevara Gonzalez points to how migrant services are now divided between the local guides who cover short legs of a longer journey, and the coyotes who facilitate irregular migration on to the United States. Guevara Gonzalez shows how these practices lead to what Collyer (2010, 275) has termed "fragmented journeys." Notably the transit takes more time and more money, and it often involves interruptions due to bad health, running out of money, being arrested and detained, and being sent back and moving forward again.

Disrupting local economies

Tightening the borders does combat migrant smuggling networks, but it does not address the local economic dynamics that support the services of smugglers. As Achilli (this volume) suggests, the EU-Turkey statement and joint action plan, as well as the initial conception of Operation Sophia (aimed at destroying boats and dismantling smuggling networks), temporarily tackled migrant flows out of Turkey, but they did not address either the root causes of or the local economic factors in migration. Notably, the large number of small shop owners who were making a living by selling life jackets and related gear, the car owners who helped with transportation of "customers", also the owners of houses and hotels in the areas near the port of 
Mersin or Izmir where Syrians and others stayed before boarding the boats to Greece. These actors do not qualify as criminals but they have created the habitus within which migrant smuggling or facilitation takes place. As Achilli, Brachet, and Guevara Gonzalez illustrate in this volume, smuggling provides for such side-jobs and thus has its own socioeconomic dynamic.

Brachet further emphasizes this point by noting that in the Sahel such services were not always labeled as illegal and are still not considered criminal to this day. Money paid to stay at provisional shelters or to buy food and supplies and even the bribes paid to police and border guards were fed into the local economy, indirectly undermining any motivation to turn to criminal activities, such as that existing today. While the EU and the United States are spending millions to support border controls, to open international organization offices, and to build capacity in transit countries, they are at the same time taking away valuable sources of cash for local communities. It is unclear whether government funding to build migration control capacity and setting up local IOM or Frontex branches is feeding in any way into the local economies or rather exacerbating local and regional inequality.

\section{Profit and trust: Complex morality}

Economic motivations and profit, as well as social meanings of trust and community in a highly insecure environment, need to be taken into account to fully understand migration facilitation. Moving away from a simple understanding of migrant as victim and smuggler as criminal, contributions to this volume highlight the complex system of trust, interdependence, community ties, and profit that is used during the smuggling process. There are several important findings in this volume that help us to understand the complex "morality" of smuggling.

First, initial contact with and choosing the smuggler take place within the community, through the recommendation of other migrants and through relatives and co-villagers. Second, the smuggler and migrant face hardships together during the crossings. Preparations for a long and perilous journey from Senegal to the Canary Islands (see Maher, this volume), for example, reveal the boat captains' concerns for the safety of their passengers.

Ayalew (this volume) points to the accumulation of knowledge that is necessary for navigating border controls and perilous journeys. Ayalew points to the creation of communities of knowledge that involve Eritreans at home, Eritrean diasporas in neighboring (Ethiopia or the Sudan) and distant (Europe) countries, and pilots (boat captains) who navigate high danger areas and avoiding kidnappings or death. Similarly, Achilli (this volume) points to the hardship shared by facilitators and migrants on the road from Turkey to Greece and further north.

Majidi (this volume) also discusses the role of community ties for Afghans and Somalis - two groups that have increasingly sought protection outside their own countries in the last decade. The interplay between moral obligation and economic profit and dependence is very tight. At the end of the day, the intermediary, the hawala (Afghanistan) or the dahabshiil (Somalia), keeps the money until the journey is successfully completed; this guarantees that the initial trust is honored and the service is provided.

Slack and Martinez's contribution offers an interesting distinction between satisfaction with the service and trust in one's smuggler. While satisfaction with a smuggler is affected by the success of the journey, recommending a smuggler to a close relative has more to do with the quality of the service en route, including safety (particularly of women) and humane treatment than with success or completion of the journey.

All contributions to this volume point to the sense of moral obligation that these smugglers feel toward their customers and to the transnational systems of trust and knowledge 
that emerge from this obligation. While the policy implications of these findings may not be apparent at first glance, the findings do point to the complex role of the migrant smuggler that is not reflected in current policies and certainly not in law enforcement and to the need to go beyond a criminal justice framework to work with local origin and transit communities. Transformation of the smuggling networks

Several studies have elaborated on the distinctive roles of those involved in smuggling networks, distinguishing among local guides and transnational contacts, those who meet people at ports or airports or other arrival places and those higher up in the hierarchy who have contacts with, for instance, corrupt border guards (Antonopoulos and Winterdyk 2006; Içduygu and Toktas 2002; Içduygu 2004; Triandafyllidou and Maroukis 2012). This volume of The ANNALS contributes to a more critical and historical view of how migrant smuggling networks were formed and how they built on pre-existing local and regional relationships between and within communities. Stone-Cadena (this volume) explains how services facilitating international border crossing are embedded in historical patterns of movement, trade, and exchange across Ecuador. Blanchet argues the same for trans-Saharan crossings.

However, the tightening of borders and the increase of controls disrupt such patterns and lead to the professionalization of smuggling networks. Stone-Cadena and Alvarez-Velasco explain how indigenous coyoterismo, based on community relations of interdependence and trust, is now transformed into transnational organized crime networks that operate by phone in which relationships are impersonal and trust is replaced by dependence and fear. They convincingly argue that this change in coyoterismo has resulted because of visa restrictions that have stiffened the passage not only to the United States but also through Mexico, Guatemala, and Costa Rica, and because of the role assigned to Mexico by the United States as a buffer zone. Guevara Gonzalez also shows how these new criminal networks involve both more traditional actors, notably local guides who know the terrain, and professional facilitators, the coyotes, who arrange the unauthorized border crossing.

\section{Concluding Remarks: Diverting the Flows}

The critical analysis of migrant smuggling that I discuss here and that the articles in this volume elucidate, points to the need for a more comprehensive approach to irregular migration and asylum seeking; one that avoids categorical distinctions between victims and perpetrators, migrants and their smugglers. It also points to the disproportional focus afforded in recent years to the criminal activities of smuggling networks and points to how such networks can be the byproducts of the very restrictions that aim to combat them.

Contributions to this volume of The ANNALS point to a number of important lessons to be learned by policy-makers:

- Tightening borders and disrupting local migrant facilitation economies have important implications, albeit in the opposite direction than the one desired. Instead of discouraging migrants and dismantling smuggling networks, these policies lead to migrants investing more money and facing more risks (and often death) along their journeys, while the networks become professionalized. Trust and community relationships are increasingly replaced by pure profit-seeking and dependence, leading to higher risks and more ruthlessness. 
- Border controls and the fight against migrant smuggling need to take into account wider regional political and economic processes. For instance, the fall of the Khaddafi regime in Libya and the concomitant dismantling of the Libyan oil economy have deprived both earlier migrants and natives of their local means of subsistence. Further regional economic factors have escaped the radar of European and international policymakers, such as the closure of gold mines in Djado and Air mountains in Niger and the resulting unemployment of young (and armed) local men (see Brachet in this volume).

- The war in Syria, conflict in Somalia, oppression in Eritrea, insecurity in Afghanistan, inhospitable treatment of Afghans in Iran, poverty and lack of hope in Central America, all lead to strong motivations for moving. Such motivations cannot be offset by tightening borders and criminalizing smugglers. There is an urgent need to work with origin and transit countries so as to (a) develop bilateral schemes for temporary or long term employment that would ease migration pressures by providing realistic labour migration options for both highly and low skilled migrants (see also Triandafyllidou, 2017 on a sectorial approach to labour migration management). Such examples have worked for instance in the Mediterranean region between Morocco and Spain for employment in the agricultural sector (Gonzalez Enriquez 2013) and also between Slovakia and Austria in the care sector (Humer and Hrzenjak 2015);

(b) to develop information campaigns through the involvement of local associations in the countries of origin and transit as to the dangers of irregular migration and migrant smuggling and the difficult conditions that migrants will face not only en route but also upon arrival (lack of rights, lack of employment, very poor living conditions, risk of arrest and expulsion);

(c) to develop international schemes of responsibility sharing for asylum seekers. The emergency quotas for the relocation of asylum seekers among European Union member states is a first, partly successful experiment on how to deal with massive arrivals of people seeking international protection (European Commission 2017). Perhaps more can be learnt from the UN scheme for the Vietnamese boat people in the late 1970s and more recently which sough to distribute refugees worldwide (Chetty 2001).

- [?/ How? What does it mean for policymakers to "work with origin and transit countries..."? What does that look like in real life? This bullet point and the one below highlight a critical policy question that this volume renders beautifully and that you point to here: in an increasingly global economy that's regarded by most as increasingly dangerous, how can national / international migration policy effectively respond to what seems to be a preponderance of empirical evidence that nations' attempts to protect their interests through border control and militarization seems to not be working? Can you point to an enlightened example of evidence-informed migration policy? Do you have suggestions of your own?]

- Last, there is a need for a wider understanding of the monetary value of border control. The EU and the United States spend millions in fencing and gatekeeping (Triandafyllidou and Ambrosini 2011), employing not only border guards but also buying expensive border control equipment like infrared cameras, thermic sensors, or radars. In addition, they invest a lot of money to build capacity in transit countries in Central America as well as in North Africa and the Sahel. Such money does not trickle down to the local or national economies. It is often international experts who are employed in these offices who will not spend their money locally (see also Brachet 2016). The funds 
resulting from the EU-Turkey agreement do not address the grievances of cross border communities either in southeast or in southwest Turkey that had profited from the smuggling business. The investment of Mexican and Moroccan authorities in their border control capacity does not help to address the root causes of West African or Central American transit flows. Increased enforcement risks only exacerbating the violence of police forces and ruthlessness of smugglers while the flows are at best diverted to other routes.

\section{References}

Antonopoulos, George A., and John Winterdyk. 2006. The smuggling of migrants in Greece: An examination of its social organization. European Journal of Criminology 3:439-61.

Brachet, Julian. 2016. Policing the desert. The IOM and Libya beyond war and peace. Antipodes 48 (2): 272-92.

Chetty, Lakshmana (2001) Resolution Of The Problem Of Boat People: The Case For A Global Initiative

ISIL Year Book of International Humanitarian and Refugee Law, available at http://www.worldlii.org/int/journals/ISILYBIHRL/2001/8.html last accessed on 15 December 2017.

Collyer, Michael 2010. Stranded migrants and the fragmented journey. Journal of Refugee Studies 23, (3): 273-93.

Douglas S. Massey, Jorge Durand, and Karen A. Pren, "Why Border Enforcement Backfired," American Journal of Sociology 121, no. 5 (March 2016): 1557-1600.

https://doi.org/10.1086/684200

Düvell, Franck, ed. 2006. Illegal immigration in Europe: Beyond control? Houndmills: Palgrave/ Macmillan.

European Commission (2015) Brussels, 27.5.2015 COM(2015) 285 final COMMUNICATION FROM THE COMMISSION TO THE EUROPEAN PARLIAMENT, THE COUNCIL, THE EUROPEAN ECONOMIC AND SOCIAL COMMITTEE AND THE COMMITTEE OF THE REGIONS EU Action Plan against migrant smuggling (2015 2020) available at https://ec.europa.eu/antitrafficking/sites/antitrafficking/files/eu_action_plan_against_migrant_smuggling_en.pdf last accessed on 15 December 2017.

European Commission (2017) Brussels, 26.7.2017 COM(2017) 405 final REPORT FROM THE COMMISSION TO THE EUROPEAN PARLIAMENT, THE EUROPEAN COUNCIL AND THE COUNCIL Fourteenth report on relocation and resettlement https://ec.europa.eu/home-affairs/sites/homeaffairs/files/what-we-do/policies/europeanagenda-migration/20170726_fourteenth_report_on_relocation_and_resettlement_en.pdf

Gonzalez Enriquez, C. (2013) Circularity in a Restrictive Framework: Mobility between Morocco and Spain, in A. Triandafyllidou (ed) Circular Migration between Europe and its Neighbourhood, Oxford: OUP, pp. 114-141. 
Humer, Z. and Hrzenjak, M. (2015) When the State Steps in: An experiement of subsidised hiring of domestic workers in Slovenia, in A. Triandafyllidou and S. Marchetti (eds) Employers, Agencies and Immigration, Aldershot: Ashgate, pp. 169-189.

Içduygu, Ahmed, and S. Toktas. 2002. How do smuggling and trafficking operate via irregular border crossings in the Middle East? Evidence from fieldwork in Turkey. International Migration 40 (6): 25-54.

Içduygu, Ahmed. 2004. Transborder crime between Turkey and Greece: Smuggling of migrants and its regional consequences. Southeast European and Black Sea Studies 4 (2): 294314.

Koser, Khalid 2010. Dimensions and dynamics of irregular migration. Population, Space and Place 16 (3): 181-93.

Kyle, David, and Rey Koslowski, eds. 2001. Global human smuggling: Comparative perspectives. Baltimore, MD: The Johns Hopkins University Press.

Mountz, Alison (2010) Seeking Asylum. Human Smuggling and Bureaucracy at the Border, Minneapolis: University of Minnesota Press.

Pliez, Olivier. 2003. Villes du Sahara. Urbanisation et urbanite dans le Fezzan libyen. Paris: CNRS.

Salt, John, and J. Stein. 1997. Migration as a business: The case of trafficking. International Migration 35 (4): 467-94.

Sanchez, Gabriella. 2015. Human smuggling and border crossings. New York, NY: Routledge.

Triandafyllidou, Anna, and Maurizio Ambrosini. 2011. Irregular immigration control in Italy and Greece: Strong fencing and weak gate-keeping serving the labour market. European Journal of Migration and Law 13:251-73.

Triandafyllidou, Anna, and Thanos Maroukis. 2012. Migrant smuggling: Irregular migration from Asia and Africa to Europe. London: Palgrave.

Van Hear, Nicholas, with Rogers Brubaker and T. Besa. 2009. Managing mobility for human development: The growing salience of mixed migration. United Nations Development Programme, Human Development Reports 2009/20.

Van Liempt, Ilze 2007. Navigating borders: Inside perspectives on the process of human smuggling into the Netherlands. Amsterdam: Amsterdam University Press.

\section{Notes}

\footnotetext{
${ }^{1}$ The term 'digital borders' refers to the increased securitization of passports and visas through the insertion of holograms and electronic chips that make them hard to counterfeit.

2 For the UNODC see http://www.unodc.org/unodc/en/human-trafficking/smuggling-ofmigrants.html?ref=menuside and for IOM see: http://www.iom.int/jahia/Jahia/pid/748.

${ }^{3}$ https://www.europol.europa.eu/about-europol/european-migrant-smuggling-centre-emsc.
} 